\title{
Determination of Catechol in Cigarette Smoke Condensate by High-Performance Liquid Chromatography (HPLC) Analysis with an Automated Precolumn Sample Preparation*
}

\author{
by $B$. Gerstenberg and $M$. Speck \\ INBIFO Institut für biologische Forschung $\mathrm{GmbH}, \mathrm{Köln}$
}

\section{SUMMARY}

A procedure has been developed for a simple and specific determination of catechol in cigarette smoke condensate. The analysis is performed by high-performance liquid chromatography (HPLC) with column switching between a precolumn and an analytical column. Catechol is separated from most of the condensate components by selective adsorption on a dihydroxyboryl silica gel precolumn. It is then determined without interference on a reverse-phase $\left(\mathrm{C}_{18}\right)$ column. By column switching this procedure is run automatically within $15 \mathrm{~min}$. The method is well suited for the routine measurement of a large number of samples, since it allows condensate solutions to be injected directly into the analysis system without prior laborious and time-consuming clean-up procedures.

\section{ZUSAMMENFASSUNG}

Es wurde eine unkomplizierte Methode zur spezifischen Bestimmung von Brenzcatechin im Zigarettenrauch mittels Hochleistungsflüssigkeitschromatographie (HPLC) und Säulenschaltung entwickelt. Brenzcatechin wird durch selektive Adsorption auf einer Dihydroxyboryl-Vorsāule von dem größten Teil der Kondensatbestandteile abgetrennt. Anschließend kann Brenzcatechin auf einer ${ }^{\text {reverse-phase }}{ }^{*}$-Säule $\left(\mathrm{C}_{18}\right)$ vollstāndig abgetrennt und bestimmt werden. Durch Säulenschaltung läuft die Bestimmung automatisch in 15 Minuten ab. Die Methode erfordert keine zusätzliche Probenvorbereitung und eignet sich besonders für Reihenuntersuchungen.

\footnotetext{
* Received: 18th December 1985 - accepted: 24th April 1986.
}

\section{RESUME}

Une méthode simple et spécifique a été mise au point pour l'identification et le dosage du catéchol contenu dans le condensat de la fumée de cigarette. Cette analyse est effectuée par chromatographie en phase liquide a haute performance (HPLC) en couplant deux colonnes. Le catéchol est séparé de la plupart des autres composés du condensat par adsorption sélective sur un gel de silice dihydroxyborique placé dans la première colonne. A la suite de cette opération, le catéchol peut être séparé complètement et dosé sur une colonne à phase inversée $\left(\mathrm{C}_{18}\right)$. Grâce au couplage des colonnes, le dosage s'effectue automatiquement en 15 minutes. Cette méthode, qui ne demande aucune purification préliminaire, convient par conséquent à l'analyse d'un grand nombre d'échantillons.

\section{INT'RODUCTION}

Catechol can be produced by the pyrolysis of plant material (1) and is therefore found in cigarette smoke condensate. Many of the methods for the determination of catechol in cigarette smoke are based on different liquid-liquid extraction steps followed by photometric detection or thin-layer chromatography (2-4). Analysis using gas chromatography has also been used $(5,6)$. However, most of these methods are laborious or, if less sample preparation is conducted, not specific for catechol. JEANTY et al. (7) used high-performance liquid chromatography (HPLC) to determine phenols in cigarette smoke condensates, but only monophenols.

The method described here is based on the selective isolation of catechol as a vicinal dihydroxy compound by complexation with borate in a weakly alkaline or neutral medium. This principle, which has already been 
used in liquid-liquid extraction $(3,4)$, is applied to liquid-solid partitioning using a reverse-phase material, with bonded boric acid functions, in an HPLC precolumn.

\section{EXPERIMENTAL}

\section{Instrumentation}

The analyses were performed on a Hewlett-Packard model 1084 B high-performance liquid chromatograph with automatic sampler, variable wavelength detector, integrator and column switching valve (Rheodyne, model 7040). The precolumn ( $40 \mathrm{~mm} \times 4.6 \mathrm{~mm}$ inside diameter) was dry-filled with dihydroxyboryl= Si100Polyol, $30 \mu \mathrm{m}$ (Serva, Heidelberg). The analytical column ( $200 \mathrm{~mm} \times 4.6 \mathrm{~mm}$ inside diameter) was prepacked with LiChrosorb RP-18, $10 \mu \mathrm{m}$ (Hewlett-Packard, Böblingen).

\section{Chemicals}

Acetone, sodium dihydrogen phosphate, phosphoric acid, catechol and pyrogallol were of analytical grade; methanol of chromatographic grade. All chemicals were purchased from E. Merck, Darmstadt.

\section{Sample Material}

The cigarette used in the investigation was the University of Kentucky standard reference cigarette $2 \mathrm{R} 1$. The smoke was generated on a 30-port smoking machine (8) and the condensate collected with an impaction trap (9).

\section{Sample Preparation}

Immediately after collection, the condensate was suspended in acetone at a concentration of $25 \mathrm{~g} / 1$. The acetone contained pyrogallol $(1.25 \mathrm{~g} / \mathrm{l})$ as an internal standard. The suspension was centrifuged at $20000 \mathrm{~m} / \mathrm{s}^{2}$ for $3 \mathrm{~min}$ and the supernatant was directly used for HPLC analysis.

\section{HPLC Determination}

In the first step catechol was selectively adsorbed on the dihydroxyboryl precolumn while the major components of the condensate were washed into the waste with methanol (status 2 in Figure 1). In the second step the precolumn was switched on-line to the analytical column (status 1 in Figure 1) and the compounds bound by the precolumn were eluted onto the analytical column by means of an acidic eluent. These compounds were then separated by gradient elution.

The elution solvents were a phosphate buffer of $\mathrm{pH}=$
Flgure 1.

Schematic dlagram of the HPLC equipment.
Equipment status 1

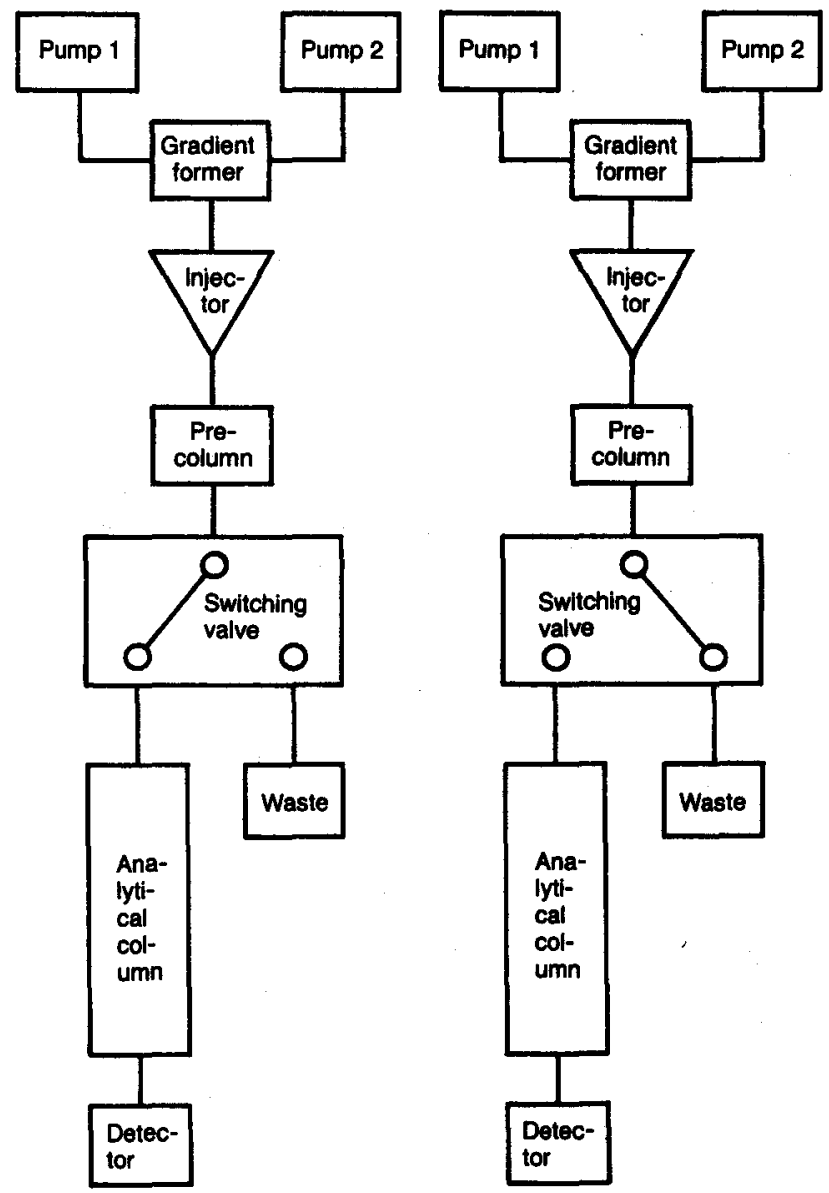

2.8 (10 mM sodium dihydrogen phosphate, $\mathrm{pH}$ adjusted with phosphoric acid) and methanol. The flow rate was $1.5 \mathrm{ml} / \mathrm{min}$ and the injection volume was $20 \mu \mathrm{l}$. The detection was performed at $280 \mathrm{~nm}$. The program steps of the chromatographic run are listed in Table 1 and the chromatograms shown in Figure 2.

\section{RESULTS AND DISCUSSION}

The high affinity between the borate groups attached to the precolumn material and catechol allowed it to be isolated from a non-aqueous solution. Therefore a condensate solution in acetone could directly be injected and the dihydroxyboryl precolumn be washed with methanol without loss of catechol. Thus, sample preparation was reduced to suspension of the condensate and centrifugation. Besides minimizing the sample preparation steps and consequently the possibilities of error, the method has another advantage. In contrast to the other methods which use liquid-liquid extractions, 
Table 1.

Program steps in the high-pertormance llquid chromatography (HPLC) procedure.

\begin{tabular}{|c|c|c|c|c|}
\hline $\begin{array}{l}\text { Time } \\
(\min )\end{array}$ & Operation & $\begin{array}{c}\text { Mobile } \\
\text { phase } \\
\text { (meth- } \\
\text { anol } \\
\text { in \%) }\end{array}$ & $\begin{array}{l}\text { Equip- } \\
\text { ment } \\
\text { status }\end{array}$ & Effect \\
\hline 0.0 & $\begin{array}{l}\text { Injection, } \\
\text { setting of } \\
\text { the baseline }\end{array}$ & 100 & 1 & - \\
\hline 0.1 & $\begin{array}{l}\text { Column } \\
\text { switching }\end{array}$ & 100 & 2 & $\begin{array}{l}\text { Adsorption of catechol } \\
\text { and other dihydroxy } \\
\text { compounds on } \\
\text { precolumn }\end{array}$ \\
\hline 1.0 & $\begin{array}{l}\text { StL } \\
\text { gradient }\end{array}$ & 100 & 2 & $\begin{array}{l}\text { Adsorption of catechol } \\
\text { and other dihydroxy } \\
\text { compounds on } \\
\text { precolumn }\end{array}$ \\
\hline 2.0 & $\begin{array}{l}\text { End of } \\
\text { gradient }\end{array}$ & 5 & 2 & $\begin{array}{l}\text { Adsorption of catechol } \\
\text { and other dihydroxy } \\
\text { compounds on } \\
\text { precolumn }\end{array}$ \\
\hline 2.1 & $\begin{array}{l}\text { Column } \\
\text { switching }\end{array}$ & 5 & 1 & $\begin{array}{l}\text { Transfer from } \\
\text { precolumn to analytical } \\
\text { column }\end{array}$ \\
\hline 3.5 & $\begin{array}{l}\text { Start of } \\
\text { gradient }\end{array}$ & 5 & 1 & Separation \\
\hline 13.5 & - & 70 & 1 & $\begin{array}{l}\text { Washing of the } \\
\text { columns }\end{array}$ \\
\hline 15.0 & $\begin{array}{l}\text { End of } \\
\text { gradient }\end{array}$ & 100 & 1 & $\begin{array}{l}\text { Equilibration for next } \\
\text { analysis }\end{array}$ \\
\hline 22.0 & Stop & 100 & 1 & $\begin{array}{l}\text { Equilibration for next } \\
\text { analysis }\end{array}$ \\
\hline
\end{tabular}

all contact with alkaline medium, which is known to give rise to losses by oxidation, could be avoided.

The isolation on the precolumn and the separation on the analytical column could be achieved with only 2 pumps, as the solvents for adsorption and desorption of catechol on the precolumn were parts of the solvent gradient for the subsequent analytical separation. Because of the different selectivities of the 2 columns the elution capacity of the acidic buffer for catechol was high for the dihydroxyboryl precolumn and low for the reverse-phase column. This fact caused the sample to be concentrated on the top of the analytical column and prevented peak broadening even with large injection volumes.

Pyrogallol was chosen as the internal standard since it has vicinal hydroxyl groups like catechol and was therefore selectively adsorbed on the precolumn. Because of its higher polarity, pyrogallol was eluted from the reverse-phase column about 2 min before catechol and showed no interference with other components of the condensate.

The identity of the catechol was confirmed by its reten-
Figure 2.

HPLC chromatograms of [A] a standard solution (pyrogallol: $1.25 \mathrm{~g} / \mathrm{l}$, catechol: $0.10 \mathrm{~g} / \mathrm{l}$ ) and [B] a 2R1 condensate solution (25 g/l). Precolumn: dihydroxyboryl=Si100Polyol (30 $\mu \mathrm{m}$, $40 \mathrm{~mm} \times 4.6 \mathrm{~mm})$; analytical column: LiChrosorb RP-18 $(10 \mu \mathrm{m}$, $200 \mathrm{~mm} \times 4.6 \mathrm{~mm}$ ); mobile phase: $10 \mathrm{~mm}$ sodium dihydrogen phosphate buffer of $\mathrm{pH}=2.8$ / methanol (composition: see Table 1); flow rate: $1.5 \mathrm{ml} / \mathrm{min}$; room temperature; UV detection: $280 \mathrm{~nm}$.

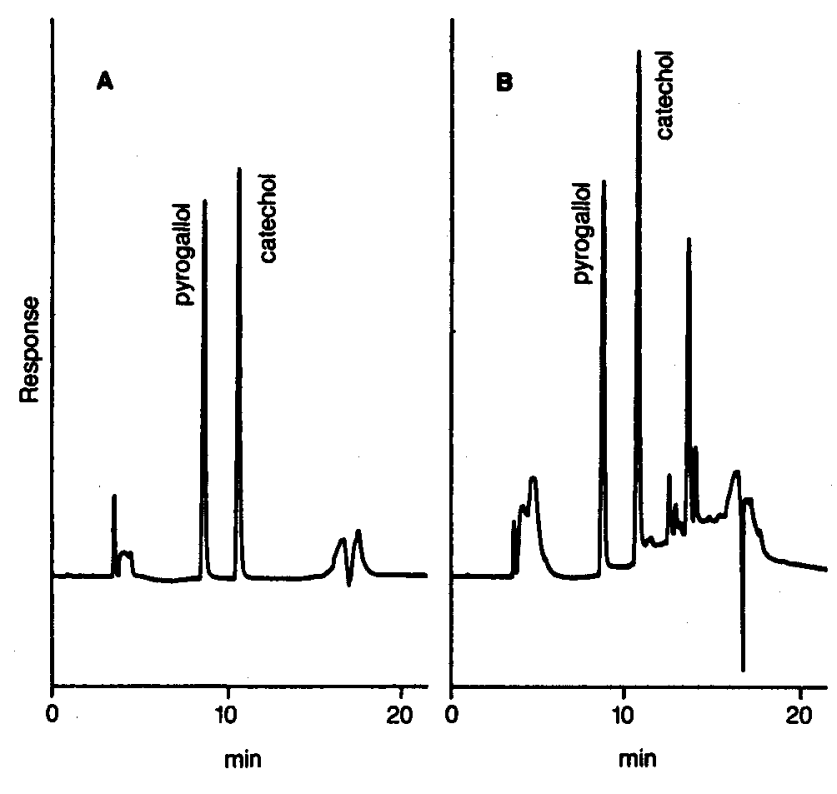

tion time, by the method of standard addition, and by its UV absorption spectrum.

For correct setting of the baseline, it was important that the column effluent passed through the detector cell at the start of the analysis. Therefore the columns had to be on-line at the beginning (status 1 in Figure 1). Afterwards they were immediately switched off-line (status 2 in Figure 1) for the washing of the precolumn. A washing time of $1 \mathrm{~min}$ was found to be enough for the removal of the major condensate compounds which were not adsorbed.

After the analysis the phosphate buffer had to be completely displaced by methanol before processing another sample because catechol cannot form a stable borate complex in an acidic medium. An equilibration time of $7 \mathrm{~min}$ was found to be adequate for this purpose.

The precolumn was used for the analysis of at least 500 condensate samples without any decrease in chromatographic resolution. The catechol in the cigarette smoke condensate samples (dissolved in acetone containing pyrogallol as internal standard) was found to be stable at $-18^{\circ} \mathrm{C}$ during storage time of up to 6 weeks.

The relative standard deviation of the method was $1.5 \%$ based on 10 determinations conducted on the same condensate solution. For the determination of recovery, catechol was added in an amount equal to that originally in the condensate. The recovery was found to be $99 \%$. The method was checked for linearity of the 
catechol concentration in the range from 20 to $400 \mathrm{mg} / \mathrm{l}$. The correlation coefficient was $r=0.996(n=7)$.

The mean catechol concentration in the $2 \mathrm{R} 1$ cigarette smoke condensate was determined to be $5.0 \mathrm{mg} / \mathrm{g}$ condensate $(n=60$, relative standard deviation $=6.2 \%)$, which is equivalent to a delivery of $199 \mu \mathrm{g}$ /cigarette. BrunNemann et al. (4) found a range of 136 to $328 \mu \mathrm{g}$ / cigarette for various non-filter cigarettes. GuERIN and Olerich (5) found $190 \mu \mathrm{g} /$ cigarette for the IR1 cigarette.

\section{CONCLUSION}

Compared to conventional methods the proposed HPLC method provides a rapid and simple procedure with low background effects because of its high selectivity. The only sample preparation steps are suspension of the condensate in acetone and centrifugation. Further clean-up is integrated into the HPLC procedure which is run automatically.

Although the procedure has specifically been developed for the determination of catechol in cigarette smoke condensates, it is expected that it could be applied to the analysis of the condensates or pyrolyzates derived from other types of organic matter.

\section{REFERENCES}

1. Carmella, S. G., S. S. Hecht, T. C. Tso and D. Hoffmann: Roles of tobacco cellulose, sugars and chlorogenic acid as precursors to catechol in cigarette smoke; J. Agric. Food Chem. 32 (1984) 267-273.

2. Waltz, P., M. Häusermann and A. Krull: Methoden der quantitativen Bestimmung des Brenzcatechins im Cigarettenrauch; Beitr. Tabakforsch. 3 (1965) 263277.
3. Mold, J. D., M. P. Peyton, R. E. Means and T. B, Walker: Determination of catechol in cigarette smoke; Analyst 91 (1966) 189-194.

4. Brunnemann, K. D., H.-C. Lee and D. Hoffmann: Chemical studies on tobacco smoke, 47. On the quantitative analysis of catechols and their reduction; Anal. Lett. 9 (1976) 939-955.

5. Guerin, M. R., and G. Olerich: Direct gas chromatographic determination of catechol in cigarette smoke; Tob. Int. (N. Y.) 178, No. 4 (1976) 17-21.

6. Ishiguro, S., and S. Sugawara: Gas chromatographic analysis of cigarette smoke by trimethylsilylation method; Beitr. Tabakforsch. Int. 9 (1978) 218- 221.

7. Jeanty, G., J. Massé and P. Berçot: Quantitative analysis of cigarette smoke condensate monophenols by reverse-phase high-performance liquid chromatography; Beitr. Tabakforsch. Int. 12 (1984) 245250.

8. Deutsches Institut für Normung, DIN 10240: Maschinelles Abrauchen von Zigaretten und Bestimmung des Rauchkondensats, parts 1 and 2 (April 1978).

9. Mathewson, H. D.: The direct preparation of cigarette smoke condensate by high velocity impaction; Beitr. Tabakforsch. 3 (1966) 430-437.

\section{Acknoroledgement}

The dibydroxyboryl precolumn material (dibydroxyboryl=Si100Polyol) was kindly supplied by Serva Feinbiochemika GmbH, Heidelberg, West Germany.

\section{Autbor's address:}

INBIFO Institut für biologische Forschung,

Fuggerstraße 3,

D-5000 Köln 90. 